\title{
Self-knowledge as religious experience. On an aspect of Kant's conception of the vocation of human beings
}

Autoconocimiento como experiencia religiosa. Acerca de un aspecto de la concepción kantiana de la vocación de los seres humanos

\section{GABRIELE TOMASI}

Dipartimento di Filosofia, Sociologia,

Pedagogia e Psicologia Applicata

Università degli Studi di Padova

I-35139 Padova (Italia)

gabriele.tomasi@unipd.it

Abstract: In this paper, I will deal with an aspect of Kant's conception of our vocation (Bestimmung). I will argue that the way Kant conceives of our "higher" vocation, namely in terms of a vocation to moral selflegislation, allows for a religious experience of ourselves and in ourselves. In understanding herself in relation to the holiness of her pure will, a person might have a religious experience of herself, conceiving of her duties as divine commands, whilst also in a sense experiencing God in herself -in her personality.

Keywords: Vocation, self-legislation, selfexperience, religion, Kant.
Resumen: En este artículo trataré un aspecto de la concepción kantiana de nuestra vocación (Bestimmung). Argumentaré que la manera en que Kant concibe nuestra "más alta" vocación, concretamente en términos de una vocación a una autolegislación moral, tiene en cuenta una experiencia de nosotros mismos y en nosotros mismos. Al entenderse alguien en relación a la santidad de su voluntad pura, una persona puede tener una experiencia religiosa de sí misma, entendiendo sus deberes como mandatos divinos, al mismo tiempo que también en un sentido teniendo experiencia de Dios en sí misma —en su personalidad-.

Palabras clave: Vocación, autolegislación, experiencia de sí mismo, religión, Kant. 
W e human beings can deceive ourselves in many ways. For example, we can hide the true reasons for our actions from ourselves; we can avoid seeing what is right before us, perhaps because it hurts. Kant knows these phenomena very well. However, he also shows that and how we can misunderstand, or not clearly comprehend, who we are, thereby neglecting true possibilities of self-realization and a meaningful life. According to Kant, this happens when we lead our life as an animal endowed with reason -namely, in his terms, as if our sensible self were our whole self.

In Kant's time, questions of self-understanding and self-realization were discussed under the heading of the 'vocation (Bestimmung) of the human being'. ${ }^{1}$ In fact, the question of our vocation was primarily understood to pertain not to our essence or what we are, but to who we should become. Its significance was therefore more existential than intellectual. To ask about our vocation was to ask why we are here, which is fundamentally to ask about the meaning of our lives.

In this paper, I will deal with an aspect of Kant's conception of our vocation. I will argue that the way he conceives of our 'higher' vocation, namely in terms of a vocation to moral self-legislation, allows for a religious experience of ourselves and in ourselves. The expression 'religious experience' is notoriously vague; both of its central terms are difficult to define. I will therefore use this term in a rather loose way, to denote the experience of something religiously significant: an experience that seems to the person having it to have religious relevance and to be of something that is objectively real. ${ }^{2}$ In the Christian tradition to which Kant belongs, though he filters its content through the concepts of pure practical reason, the object of religious experiences is typically God himself, understood as an

1. The origin, context, and implications of the vocation question are masterfully described by R. BRANDT, Die Bestimmung des Menschen bei Kant (Meiner, Hamburg, 2007) 8-177. In this paper I deal only with the personal or individual side of the question. However, as Brandt highlights, it also has a social side, concerning what we might call our collective vocation, as members of mankind, to become members of a civil society.

2. Cf. R. Audi, Rationality and Religious Commitment (Clarendon Press, Oxford, 2011) 108-109. 
eternal, omniscient, omnipotent, free, and perfectly good being (cf. e.g. $K U$ 5:444). ${ }^{3}$ Since God is no ordinary spatiotemporal object, this obviously puts pressure on our common-sense conception of experience as a way to acquaint ourselves with ordinary objects and some of their properties and relations. However, in speaking of a religious experience, I do not refer to the idea of a perceptual experience of God, although perceptual aspects are involved in religious experiences.

Both versions of the religious experience I have in mind - the of- and the in-ourselves versions - are closely connected to the concept of duty that lies at the core of Kant's ethics. In light of this, I will begin by briefly commenting on a passage from the Critique of Practical Reason (1788), in which Kant reflects on the origin of duty in a somewhat emphatic way. The rest of the paper is an attempt to unpack a couple of notions appealed to in the passage, the first of which is that of the higher vocation of human beings.

\section{ON THE VOCATION OF THE HUMAN BEING TO MORAL SELF-DETERMINATION}

Kant sees something wonderful and mysterious in duty -in the way it asks for submission not by threatening anything that would arouse aversion or terror in the mind, but by simply holding forth "a law that of itself finds entry into the mind and yet gains reluctant reverence (though not always obedience)". This raises the question of its origin: "what origin is there worthy of you, and where is to be found the root of your noble descent"? Interestingly, in asking this question, Kant also suggests that being grounded in this root "is the indispensable condition of that worth which human beings alone

3. Except for the Critique of Pure Reason, which is cited by page numbers in the original first (A) and second (B) editions, citations of works by Kant refer to the volume and page number in the Academy edition, Kant's gesammelte Schriften, Deutsche Akademie der Wissenschaften (formerly: Preußische Akademie der Wissenschaften), Walter de Gruyter, Berlin 1900ff. Translations are taken from P. Guyer, A. W. WoOD (eds.), The Cambridge Edition of the Works of Immanuel Kant (Cambridge University Press, Cambridge/New York, 1992 ff.). 
can give themselves" ( $K p V$ 5:86). As he emphasizes, the "root" of duty is what elevates a human being "above himself (as a part of the sensible world)", connecting him "with an order of things that only the understanding can think". This order of things, Kant further explains, "has under it (unter sich) the whole sensible world and with it the empirically determinable existence of human beings in time and the whole of all ends" (KpV 5:86). He then gives a name to the origin of duty: "personality", that is, in his view, "freedom and independence from the mechanism of the whole of nature", but considered also "as a capacity of a being subject to special laws — namely pure practical laws given by his own reason" (KpV 5:87).

As these passages show, Kant's conception of the origin of duty characterises human beings as belonging to two worlds. He thinks that, belonging to the sensible world, human beings are subject to their own personality, and they are subject to it because they also belong "to the intelligible world", which is the ground of the sensible world. For the purposes of this paper, it is not important to enter into Kant's argument. Instead, I point out two lexical choices Kant makes in this context. In relation to the human being, he makes use of the word "reverence" (Verebrung): "it is then not to be wondered at that a human being, as belonging to both worlds, must regard his own nature in reference to his second and highest vocation (böchste Bestimmung) only with reverence (Verebrung), and its laws with the highest respect (Acbtung)". Furthermore, Kant also claims that there is something in the human being - he calls it "bumanity in his person" - that should be "holy" or inviolable (unverletzlich) "to him" (KpV 5:87).

"Reverence" and "holiness" are words that have a religious connotation. Is Kant making room for the idea that human beings should have a sort of religious attitude toward themselves? Or is he hinting at a possible presence of the divine (or of something divine) in the human being? A key element in answering these questions is the notion of a highest vocation of human beings, articulated in an above passage. Kant seems to claim that the object of reverence is not human beings per se, but their nature in reference to their second and highest vocation. Speaking of a "second" and "highest" 
vocation of the human being ( $K p V 5: 87)$ implies a first and somehow lower vocation.

Actually, Kant claims that human beings have two vocations: one related to their animal nature (Tierbeit) and another related to humanity (Menschbeit) (cf. Anth-Friedländer 25:682). While our first vocation concerns our conservation as individuals and as a species, the vocation related to humanity might be interpreted in two ways, or better: human beings might interpret their vocation to humanity in two ways. This is reflected in Kant's use of the term "humanity". In fact, he sometimes uses "humanity" descriptively to express the peculiarity of the human being as an animal or a living being endowed with reason; at other times, as in the expression "the bumanity in his person", Kant gives a more normative connotation to the word and uses it to mean "personality" (in the moral sense). In this case, the meaning of "humanity" involves the concepts of freedom and self-legislation. ${ }^{4}$

Taking "humanity" descriptively, we have a first perspective on our vocation. Kant speaks of the raising of the human being from his animality "toward humanity" as an ascent toward a condition "by which he alone is capable of setting himself ends" (MS 6:387). Now, the capacity to set oneself an end presupposes conceptual skills and an ability to discriminate; it thus depends on the intellect as a faculty of concepts and a capacity to form judgments (cf. KU 5:431). Our vocation to humanity is strictly connected to the development of this kind of rationality, which, it is worth noting, is not restricted to the moral sphere: being able to set ends includes the capacity to set not only moral but also immoral and morally irrelevant ends. Consequently, 'humanity' refers to human beings, independently of their being good or bad. ${ }^{5}$ A more substantive sense of 'rationality'

4. On the different meanings of "person" and "personality" in Kant cf. M. BAUM, Person und Persönlichkeit bei Kant in A. Lohmar, H. Peucker (eds.), Subjekt als Prinzip? Zur Problemgeschichte und Systematik eines neuzeitlichen Paradigmas (Königshausen \& Neumann, Würzburg, 2004) 81-92, and M. BAUM, Subjekt und Person bei Kant, in J. Chotas, J. KaráseK, J. Stolzenberg (eds.), Metaphysik und Kritik. Interpretationen zur "Transzendentalen Dialektik" der Kritik der reinen Vernunft (Königshausen \& Neumann, Würzburg, 2010) 237-251.

5. Cf. J. Glasgow, Kant's Conception of Humanity, "Journal of the History of 
seems also to be involved at this descriptive level, however. For example, when Kant points out that as an animal endowed with reason (animal rationabile) the human being can make of himself a rational animal (animal rationale), he also observes that the human being "has a character, which he himself creates, insofar as he is capable of perfecting himself according to ends that he himself adopts" (Anthr 7:321). The use of an expression like "perfecting himself" suggests that the ends that one chooses are not insignificant to one's becoming a rational animal. The idea of perfecting oneself seems opposed to the adoption of morally reprehensible ends.

I shall attempt to articulate this point further in light of some observations in the Critique of the Power of Fudgment (1790), where Kant places the human being in the wider context of nature as a system of ends. Kant claims that the human being may be considered the "the ultimate end (der letzte Zweck) of the creation here on earth", and this because he "is the only being on earth who forms a concept of ends for himself" (KU 5:426-427). I shall consider here neither the subtleties of the teleological context in which this thesis is introduced nor Kant's argument in support of it. ${ }^{6}$ Rather, I shall focus on the feature that he describes as being specific to human beings, namely their capacity to form a concept of ends for themselves. Now, since Kant considers it a characteristic of living beings that nothing in them is purposeless (cf. $K U$ 5:376), and since he acknowledges that living beings appear to be capable of purposive behaviour (cf. $K U 5: 33,464$ ), what he clearly wants to point out as distinctive of the human being is the capacity for reflexive, purposive behaviour. In fact, Kant conceives of an end as "the object of a concept insofar as the latter is regarded as the cause of the former" (KU 5:220). To form a concept of an end for oneself thus implies the ability to act in accord with possession of that concept, which means to act according to a reason or, in Kant's conception, to have a will. ${ }^{7}$

Philosophy" 45 (2007) 291-308.

6. Cf. on this O. HöFFE, Der Mensch als Endzweck (\$S 82-84), in O. HöFFE (ed.), Immanuel Kant. Kritik der Urteilskraft (Akademie Verlag, Berlin, 2008) 289-308.

7. Kant calls "will" the faculty of desire, "insofar as it is determinable only through concepts". To have a will is "to act in accordance with the representation of an 
What Kant views as distinctive of human beings is their capacity to reflect on what they do and to act for reasons.

As we have seen, it is in virtue of this ability that human beings might be considered the ultimate end of nature, or so Kant claims. However, it is interesting that he points out that such beings can occupy the position of the ultimate end only on the condition that they have "the understanding and the will" to give to nature and to themselves a relation to a final end (Endzeck), that is, to an end "that can be sufficient for itself independently of nature". An end of this sort, Kant states, "must not be sought in nature at all" (KU 5:431), because everything in nature possesses a conditioned determining ground (cf. $K U$ 5:435). Now, since it is not plausible that we give nature itself a relation to an end, presumably what Kant means is that we have to give our teleological view or interpretation of nature a relation to a final end, namely, as he further specifies, to an end "which needs no other as the condition of its possibility" (KU 5:434). Apart from this, Kant must give content to the concept of an end sufficient for itself and must also show that human beings have the capacity to set such an end for themselves.

Very briefly, a Kantian answer to these requests might run as follows. The many ends that human beings set themselves might ultimately be rooted in their striving for happiness. Happiness is "the matter" of all human ends "on earth"; it is "the sum of all the ends that are possible through nature outside and inside of the human being" (KU 5:431). But happiness, namely (according to one definition) the "entire well-being and contentment with one's condition" (GMS 4:393), is the end that human beings have in accordance with a natural necessity (cf. GMS 4:415). ${ }^{8}$ It follows from this that happiness cannot be the final end, and Kant consequently points out that making happiness "into his whole end" renders the human being "incapable of setting a final end

end" (KU 5:220).

8. Kant also defines happiness as "the greatest sum (in terms of number as well as duration) of the agreeableness of life" (KU 5:208). Interestingly, he observes that the concept of happiness is not one that the human being derives "from the animality in himself" (KU 5: 430). 
for his own existence and of agreeing with that end" (KU 5:431). These considerations are clearly connected to the question of the vocation of the human being. Why should taking happiness as our whole end render us incapable of setting a final end for our existence and agreeing with it?

Kant's point is presumably that we form the idea of happiness "in so many ways and with such frequent changes" (KU 5:430) that it cannot represent a point of orientation for the conduct of life. ${ }^{9}$ In his view, happiness is "a mere idea of a state" (KU 5:430), the outline of which is contributed to not only by the intellect but also by the imagination and the senses. This makes it an "unstable concept" (KU 5:430), such that if we take it as our final end, we cannot give a unified and consistent form to our lives: our lives will collapse into a muddle, reflecting back to us a confused image of who we are with the result that we cannot properly know ourselves. Kant seems to suggest that our knowing who we are depends on there being a consistent final end of our existence and action.

Once he has excluded happiness as a final end, understood as the sum of the ends that are possible through nature, Kant tries to give different content to this notion. He might have reasoned along these lines. Human beings have the capacity to set ends for themselves and to act accordingly. If they have this capacity, they also have the capacity to act independently of alien causes, which, according to Kant, is part of what we mean by 'freedom'. Now, if, in choosing their ends, human beings are not subject to lawlike determination by alien causes, they must be subject to the lawlike determination of their own causality, i.e. of their will. Kant is thinking of a law that is represented by human beings themselves "as unconditioned and independent of natural conditions but yet as necessary in itself" (KU 5:435), namely the moral law, which, in his view, is the law of freedom. That final end that we cannot find in nature, because there is nothing in nature the determining ground

9. Furthermore, it would be an end that would never be attained by the human being, since, or so Kant assumes, "his nature is not of the sort to call a halt anywhere in possession and enjoyment and to be satisfied" (KU 5:430). 
of which is not conditioned, can therefore be found by choosing in accordance with the moral law.

Interestingly, this line of thought has the consequence that the final end is not a particular object at which to aim, since the moral law essentially commands how to will rather than what to will (cf. $K p V$ 5:30). Accordingly, the final end turns out to be the human being himself as a subject of morality, that is, as a subject of an "unconditional legislation with regard to ends" (KU 5:435). As we have seen, Kant claims that, in order to be an ultimate end, human beings have to give themselves a relation to a final end. If my interpretation is correct, the relation in question is properly a relation to themselves: human beings can be the ultimate end of nature only if they put themselves in relation to their personality, which, as a moral personality, is "nothing other than the freedom of a rational being under moral law" (MS 6:223).

I think we can now understand how there might in fact be both a "lower" and a "higher" version of Kant's idea of a vocation to humanity as a vocation to self-determination. The "lower" vocation of human beings is to develop the rational capacity of setting themselves ends that are all ultimately linked to what is in fact their ultimate natural end, namely happiness. By contrast, their "higher" vocation is to be moral beings or to live in accordance with an end that is not imposed on them by nature and is instead an end of freedom. ${ }^{10} \mathrm{We}$ can substantiate this conclusion by considering the question of our vocation from the particular point of view of the distinctive feature of our nature, that is, rationality. I suggest that we might also describe the higher vocation of human beings as a voca-

10. This double vocation is reflected in what Kant says when he locates the human being in nature as a teleological system. On the one hand, he identifies culture as that which is to be promoted within the human being himself as an end through his connection to nature - where culture is understood as "the aptitude and skill for all sorts of ends for which he can use nature (external and internal)" (KU 5:430). However, on the other hand, he also claims that we can see that nature still displays a purposive attempt to make us receptive "to higher ends" than it can afford (KU 5:433). In Kant's view, nature somehow sets the conditions under which the raising of human beings from animality to humanity turns out to be a raising above nature itself, according to their "higher" vocation. 
tion to be rational beings rather than merely living beings endowed with reason, and that, in Kant's eyes, a decision to live according to our "lower" vocation amounts to a kind of misunderstanding of our rational nature.

\section{WAYS OF BEING RATIONAL}

Our basic capacity to set ends for ourselves and to act accordingly involves the use of reason, a faculty whose main interests, according to Kant, are not primarily theoretical (cf. KrV A 797/B 825-A 801/B 829). He thinks that we do not use reason primarily in relation to theoretical aims. ${ }^{11}$ Therefore, our vocation to self-determination is at the same time a question about the vocation of reason as a practical faculty, i.e. as a faculty that has influence on the will. What, exactly, is reason for?

One possibility is that we have the rational capacity to set ends, to use the means to these ends, and to organize them into the whole that we call "happiness": namely, that we have reason in order to realize the end that we have by natural necessity (cf. GMS 4:415; cf. also $K r V$ A 800/B828; KpV 5:25). However, in Kant's eyes -at least in the Groundwork of the Metaphysics of Morals $(1785)^{12}$ - rea-

11. On this Kantian belief cf. R. BRANDT, Die Bestimmung des Menschen bei Kant (Meiner, Hamburg, 2007) 22-37. A nice version of the idea might be found in $K U \$ 86$. Reflecting on the value of the world, Kant states that it is not in relation to the cognitive faculty (theoretical reason) of human beings that "the existence of everything else in the world first acquires its value, so that someone should exist who can consider the world". Rather, it is in relation to the faculty of desire that the world acquires its value, "although not that which makes" human beings "dependent on nature (through sensible impulses)", not that in regard to which the value of their existence rests on what they receive and enjoy. Kant claims that it is the value that they alone can give to themselves, and which consists in what they do, "in how and in accordance with which principles" they act, not as a link in nature but in the exercise of the freedom of their faculty of desire; i.e. "a good will is that alone by means of which" their existence "can have an absolute value and in relation to which the existence of the world can have a final end" (KU 5:443).

12. In the Critique of Practical Reason, Kant somewhat more positively acknowledges the role of reason in forming action-guiding rules with regard to happiness. As belonging to the sensible world, "the human being is a being with needs", and to this extent "his reason certainly has a commission from the side of his sensibility which he cannot refuse" (KpV 5:61). 
son's performance in the service of happiness is rather poor. Presumably, to support the idea of reason's having a different vocation, Kant underestimates reason's ability to help us to survive and promote our well-being. In fact, given the background assumption of a purposiveness of nature "in distributing its capacities (Anlagen)", emphasizing the faults of reason with regard to our desire for happiness allows Kant to argue that the "true vocation" of reason as a practical faculty is not to guide the will in regard to the satisfaction of the needs that we connect to happiness. Rather, its vocation must be that in relation to which reason is "absolutely necessary", namely the achievement of a will that is "good in itself" (GMS 4:396). But if reason is entrusted to human beings with the task of producing a good will, then their vocation to become rational beings is a vocation to produce a good will and to live in accordance with it.

Of the concept of a will that is good in itself, Kant claims that it is contained for us in the concept of duty (cf. GMS 4:397), or of the necessity of an action from respect for the moral law (GMS $4: 400$ ), which is a law of reason itself. Our vocation to become rational beings may thus be interpreted as a vocation to moral selflegislation, or to put pure reason to practical use, determining by it "what to do, and thereby forming the intention to do it". ${ }^{13}$ For Kant, this is not merely a conceptual question. Rather, in shedding light on our higher vocation as a vocation to moral self-determination, he at the same time leads us to a different understanding of ourselves.

\section{Supersensible existence}

There might be more than a hint of idealization in Kant's discourse on the "true" vocation of reason and the connected "higher" vocation of human beings. However, why he thinks that the acknowledgment of such a vocation brings with it a completely different form of self-understanding is made clear in a comment on the incentive

13. A. W. Moore, Noble in Reason, Infinite in Faculty. Themes and Variations in Kant's Moral and Religious Philosophy (Routledge, London-New York, 2003) 27. 
(Triebfeder) of pure practical reason. The comment follows the claim that this incentive is nothing other than the moral law itself. Having stated this, Kant emphasizes that the moral law has this role

[...] insofar as it lets us discover the sublimity of our supersensible existence and subjectively effects respect (Achtung) for their higher vocation in human beings, who are at the same time conscious of their sensible existence and of the dependence, connected with it, on their pathologically affected nature $(K p V 5: 88)$.

This evocative passage suggests that moral motivation comes along with an insight into a feature of our supersensible existence that Kant qualifies as its sublimity; furthermore, the passage suggests that the moral law opens up a particular self-experience in term of a feeling of respect for ourselves as moral persons. What sense can we make of Kant's notion of the supersensible existence of human beings, and of its sublimity?

As a first step, we should consider that as rational living beings we have the capacity to set ourselves ends; this capacity allows us to direct our own lives rather then merely responding to the needs or ends imposed on us by nature. On this basis, Kant makes a stronger point. He claims that the moral law reveals to us "a life independent of animality and even of the whole sensible world" (KpV 5:161). Therefore, in a basic sense, a supersensible existence is an existence independent of the sensible world, at least insofar as its determination or the determination of how to live is based on moral reflection. A supersensible existence is nothing other than our sensible existence as viewed from the standpoint of the intelligible self-consciousness of the rational being. ${ }^{14}$

14. According to Kant, the moral law "is to furnish the sensible world, as a sensible nature (in what concerns rational beings), with the form of a world of the understanding, that is, of a supersensible nature, though without infringing upon the mechanism of the former" ( $K p V 5: 43)$. As for this latter clause, its justification presents huge difficulties. Cf. R. Hanna, A. W. Moore, Reason, Freedom and Kant: An Exchange, "Kantian Review" 12 (2007) 113-133, and M. WolfF, Kant über Freiheit und Determinismus, in W. Euler, B.Tuschling (eds.), Kants "Metaphysik 
In the passage quoted above, Kant hints at the idea of the sublimity of an existence independent of the sensible world. This sublimity has a lot to do with the defining character of a supersensible existence. This kind of existence is grounded on human beings' use of reason in the service of more than the satisfaction of their needs. Kant claims that the human being is not "so completely an animal as to be indifferent to all that reason says on its own", and that he has reason also "for a higher purpose", namely to reflect on what is good or evil in itself, to distinguish it from the appraisal of what contributes to his well-being, and "to make it the supreme condition" of the latter $(K p V 5: 62)$. Now, to subordinate appraisal of what contributes to well-being to reflection on what is good or evil in itself implies a willingness to subordinate the goods that are related to happiness to the condition of agreement with the moral law. In some cases, this might mean sacrificing those goods (cf. KpV 5:76). The sublimity Kant has in mind is connected to this willingness to subordinate or sacrifice the subjective determining grounds of choice to the objective grounds of morality; however, there is sublimity in this submission only insofar as it reveals the real sublimity that Kant recognises in the fact that the person who is subject to the moral law is "at the same time lawgiving with respect to it and only for that reason subordinated to it" (GMS 4:440). ${ }^{15}$

Kant views the experience of being bound by a law imposed by our own reason fundamentally as an experience of independence from all sensible limitations, of elevation above them and transcend-

der Sitten" in der Diskussion. Ein Arbeitsgespräch an der Herzog August Bibliothek Wolfenbüttel 2009, (Duncker \& Humblot, Berlin, 2013) 27-42.

15. "There is something in us", Kant writes in The Conflict of the Faculties (1798), "that we cannot cease to wonder at when we have once seen it, the same thing that raises bumanity in its idea to a dignity we should never have suspected in the human being as an object of experience." He then specifies that what we wonder at is "our ability so to sacrifice our sensuous nature to morality that we can do what we quite readily and clearly conceive we ought to do. This ascendancy of the supersensible human being in us over the sensible, such that (when it comes to a conflict between them) the sensible is nothing, though in its own eyes it is everything, is an object of the greatest wonder; and our wonder at this moral predisposition in us, inseparable from our humanity, only increase the longer we contemplate this true (not fabricated) ideal" (7:58). 
ence of what is connected to sensibility. He uses the word 'sublimity' precisely to qualify the form that existence may take in virtue of our possessing — or rather grasping in an engaged way- the concept of duty. ${ }^{16}$

I shall summarize and add some further considerations before moving on to the core of my reflections on the religious character that a certain experience of ourselves might have. Moving from Kant's claim that human beings must regard their own nature and their higher vocation "only with reverence (Verehrung)", I have tried to clarify the object of this attitude and to unpack Kant's idea of a highest vocation of human beings. As we have seen, this higher vocation is a vocation to moral self-determination. It corresponds to the vocation of reason to produce a good will. Since the concept of a good will is for us that of duty, the higher vocation of human beings turns out to be a vocation to conduct their lives in accordance with the concept of duty. Just why we should regard the nature of human beings in reference to this vocation with reverence becomes clear when we consider that this orienting of one's life to duty discloses a supersensible aspect of that nature, namely its pure rational character.

We might corroborate this last claim by recalling some considerations by Adrian Moore on concept possession. Moore points out that to possess a concept is to make sense of things in a certain way; it is "to enter into the spirit of that concept, to have whatever outlook gives the concept its point, to live by the concept". ${ }^{17}$ Possession of a concept is a kind of knowledge. It is not knowledge that anything is the case; rather, it is knowledge of how to do certain

16. This experience of transcendence has an aesthetic counterpart in the feeling of the sublime that Kant interprets as ultimately a feeling of respect "for our own vocation" (KU 5:257) and therefore as a self-experience of human beings as moral subjects who can resist and overcome their natural needs and interests. As Kant points out, while "the beautiful prepares us to love something, even nature, without interest", the sublime prepares us "to esteem it, even contrary to our (sensible) interest" (KU 5:267).

17. Cfr. A. W. Moore, op. cit, 49. For a fascinating and sophisticated discussion of concept possession cf. 48-89. 
things. ${ }^{18}$ In the Kantian case of the concept of duty, to possess it, that is, to think and to act in keeping with it, is to live in a space of reasons for action beyond "subjective ends" - namely the ends that we set for ourselves on the basis of personal needs and inclinations. It is to live in the space of objective ends, or ends that hold "for every rational being" (GMS 4:427-428). In virtue of this, the possession of the concept of duty also gives us the outlook of a form of life in a mundus intelligibilis, or a world of rational beings (cf. GMS 4:438): to think and to act on the basis of that concept is to assume a standpoint on one's life that is the standpoint of pure practical reason. Although we view or count ourselves as member of two worlds, that is, of the sensible world and the intelligible world, as rational beings we belong to the latter, ${ }^{19}$ which also means that we belong to a kingdom of ends, or "a systematic union" of rational beings as ends in themselves and of the ends of one's own "that each may set himself" (cf. GMS 4:433). And this is because, in Kant's view, when we regard ourselves as subject to the demands of pure practical reason, we also regard ourselves as free (cf. KpV 5:4 n.) and autonomous beings, who should never be treated as mere means but always at the same time as ends in themselves.

This perspective makes sense of Kant's claim that there is something in human beings that should be treated as "holy" or inviolable (KpV 5:87). However, if we take a closer look at this "something", which he calls "bumanity" in one's person, we might be a bit bewildered. Kant equates living in accordance with the concept of duty with living in accordance with one's autonomy and being one's "proper self (das eigentliches Selbst)" (GMS 4:457). ${ }^{20}$ The double standpoint from which we can consider ourselves corresponds to the possibility of two modes of self-consciousness (cf. GMS 4:453, 458), one of which is of our proper self. Oddly enough, this self does not

18. Cf. A. W. MoOre, op. cit, 73.

19. It is worth recalling that Kant sees the intelligible world as a supersensible nature, namely as a nature (a whole in accordance with laws) not given empirically, and also as an object "of our will as pure rational beings" (KpV 5:44).

20. He then suggests that, "as a human being", a person is only "the appearance of himself" (GMS 4:457). 
seem to be one's own in the sense of one's individual or particular self. My proper self does not individuate me; in fact, it achieves the contrary. In another passage, Kant seems to identify our "proper self" with our "will as intelligence" (GMS 4:461), that is, with our will as members of the intelligible world. Now, our supersensible nature as rational beings is our existence in accordance with the moral law (cf. $K p V 5: 43$ ), which is a supra-individual principle holding "for the will of every rational being" (KpV 5:19). This means that one's will as intelligence, one's proper self, is determined by the same law. These selves are therefore qualitatively identical: they are the bumanity in our person. ${ }^{21}$

Since being one's proper self is living in keeping with the concept of duty, being (or becoming) one's proper self coincides with realizing one's higher vocation. 'Proper self' is presumably an expression that refers to the nature of human beings in reference to their highest vocation - that nature which, Kant claims, must be an object of reverence for them, as something divine. We encounter a similar result when we consider what Kant views as holy in us (cf. $K p V$ 5:87). On the one hand, Kant claims that what is holy is so because of its relation to that "which is holy in itself, and on account of which and in agreement with which alone can anything be termed holy" (KpV 5: 131-132), namely the moral law. ${ }^{22}$ However, on the other hand, Kant also maintains that the moral law is called 'holy' because it "constantly and rightly" holds before the eyes of the human being the practical idea of a will incapable of any maxim "that could not at the same time be objectively a law" (KpV 5:32), that is, the practical idea of a holy will (cf. GMS 4:414). Now, since 'proper self, 'invisible self', 'personality' (KpV 5:162), and 'pure will' seem to be interchangeable terms, they all refer to what for Kant is the 'holy in us', but this is nothing other than what makes us capable

21. Since they are not in space and time, one could argue, with Schwarz, that they are also numerically identical. Cf. G. SCHWARZ, Est Deus in nobis. Die Identität von Gott und reiner praktischer Vernunft in Immanuel Kants "Kritik der praktischen Vernunft" (Verlag TU Berlin, Berlin, 2004).

22. For a comment cf. R. THEIS, Respect de la loi, respect de la personne: Kant, "Revue Philosophique de Louvain” 103 (2005) 331-346. 
of self-legislation: our pure practical reason. It is tempting to infer that pure practical reason is something divine in us. This is a conclusion that Kant himself seems to draw; however, his words also allow for other interpretations.

\section{PuRE PRACTICAL REASON, THE HOLY IN US AND THE GOD IN US}

There is an intriguing aspect of Kant's conception. Suppose I am not wrong, and Kant did in fact think along these lines: our proper self is a pure will, and since a pure will is a holy will, there is something holy in us. Now, 'holy' is a qualification usually attributed to the divine will. Given that there is something holy in us insofar as we are the subjects of the moral law, namely both lawgiving and subordinated to that law, it seems to follow that, at least insofar as we possess pure reason, we partake of the divine. Although Kant does not think that we are purely rational, he nevertheless might have thought that there literally is something divine in us, that our (possible) partaking of the divine is connected to our sharing in pure practical reason, in virtue of which we are subjects of the moral law and our proper self. This line of thought seems to be corroborated by Kant's reference to pure practical reason as the "God in us" (cf. Op. Post. 22:130). However, the point is slippery. Should we take Kant's words literally? Does he really think that practical reason is God or, somehow more plausibly, that pure practical reason "in its personality" (Op. Post. 22:118) is the idea of God? How should we read the claim that God is moral, practical, lawgiving reason itself (cf. Op. Post. 21:145)? ${ }^{23}$

One might also doubt whether these questions make sense. On the one hand, one might read Kant's statements metaphorically:

23. To answer these questions properly, one would obviously have to consider how Kant, after his retirement in 1796, changed his view on whether rational reflection on the authority of the moral law should lead finite rational agents to believe in God's existence. I inevitably leave all this in the background. For discussion of the Opus Postumum, see E. Förster, Kant's Final Synthesis. An Essay on the Opus postumum, (Harvard University Press, Cambridge, MA-London, 2000), and G. P. BASILE, Kants Opus postumum und seine Rezeption (Kantstudien Ergänzungshefte 175, De Gruyter, Berlin, 2013) (on the reception of Kant's final, unfinished work). 
ascribing a divine nature to reason might well be a way of emphasising its superiority over our subjective ends. ${ }^{24}$ On the other hand, whether we partake of the divine is debatable. Maybe the claim that there is something holy in us does not imply that holiness is a property we possess. After all, Kant maintains that holiness as complete conformity of the will with the moral law is a perfection "of which no rational being of the sensible world is capable at any moment of his existence" (KpV 5:122). According to him, we lack that perfection, and all the moral perfection we can attain "is still only virtue" (KpV 5:128). However, he also acknowledges that a capacity to value pure practical rationality is part of our vocation; therefore, even if, as rational beings of the sensible world, we lack holiness, holiness is possible for us "in idea" (GMS 4:440), just as the production of a pure will is possible for us "in idea". ${ }^{25}$ Though we are not holy, keeping faith in the idea of holiness in the course of our lives is, for Kant, a part of our (higher) vocation. ${ }^{26}$

This view is supported by a line of thought developed by Kant in his Religion Within the Boundaries of Mere Reason (1793). At a certain point in the text, he rephrases the ideal of holiness or of " $\mathrm{Hu}$ manity (rational being in general as pertaining to the world) in its full moral perfection" in Christological terms, and of the morally perfect human being he says, quoting the Gospel of St. John (cf. 1:1-2), that he is in God "from all eternity", such that "the idea of him proceeds

24. Cf. Op. post. 22:51-52: "The categorical imperative represents all human duties as divine commands; not historically, as if [God] had ever issued certain orders to man, but as reason [presents] them through the supreme power of the categorical imperative, in the same manner as a divine person can rigorously command submission to himself."

25. In a passage of the Op. Post. 21:30 that unfortunately breaks off, Kant notes: "we are originally of divine race' with regard to our vocation and its dispositions", quoting a line by Aratus recalled in The Acts of the Apostles 17:28.

26. This interpretation requires that Kant's claim that, in the case of human beings as rational beings "one can presuppose a pure will" (KpV 5:32) should be understood as meaning not that they possess a pure will, but that they have to realize it (acting under its idea, which they actually possess). This reading seems also to be suggested by Kant's statement that holiness of will is "a practical idea, which must necessarily serve as a model to which all finite rational beings can only approximate without end" (KpV 5:32), thereby showing that a demand for holiness can be addressed to them. 
from God's being" ( $R G V$ 6:60). Leaving aside the theological and hermeneutical problems connected to an interpretation of the figure of Christ in terms of the ideal of moral perfection, namely as "the representation of an individual being as adequate to an idea" (KU 5:232), I simply note here that Kant considers it "our universal duty to elevate ourselves to this ideal (Ideal), i.e. to the prototype (Urbilde) of moral disposition in its entire purity"; in fulfilling this duty, the "very idea" of moral perfection "which is presented to us by reason for emulation (von der Vernunft uns zur Nachstrebung vorgelegt wird), can give as force" (RGV 6:61). That idea, Kant states, "resides in our morally-legislative reason", and since "we ought to conform to it [...] we must be able to" (RGV 6:62). ${ }^{27}$

Holiness, or moral perfection, is a possible end for rational beings, and as an idea it has practical reality; namely, it can and ought to have influence on the will of such beings. They should represent the "God-like human being" ( $R G V$ 6:61) as a model of humanity for themselves and follow it. This perspective helps to make sense of the claim that rational beings, at least with regard to their higher vocation, are somehow divine. A human being who acts in accord with a pure will, i.e. a holy will, follows the ideal of the God-like human being. Similarity is not identity, but this does not prevent us from saying of such a being that, at least in the determination of the will, she transcends her finiteness and becomes in a sense divine. Supposing that this makes some sense, we must face the more slippery aspect of Kant's view and attempt to interpret the "God in us" claim.

In a note belonging to the preparatory works for the Religion, Kant describes the idea of holiness as "this God in us" (AA 23:108). As we have just seen, the idea of holiness is an idea that resides in our reason; if it is a God in us, then God resides in our reason. Of note with regard to this is an intriguing parallelism in Kant's text: as the human being in his full moral perfection is said, quoting St. John, to be in God from all eternity, so the idea of a pure moral intention is said to be in our morally-legislative reason. Now, the

27. On this cf. L. Pasternack, Kant on Religion within the Boundaries of Mere Reason (Routledge, London-New York, 2014) 133-141. 
morally perfect human being is an instance of that idea; therefore, it is tempting to consider pure practical reason itself as the God in whom the idea of moral perfection lies. Is pure practical reason ultimately the God in us, or is this just a way of expressing its unconditioned normative character?

It may be useful to look at this question from a slightly different point of view, namely in light of one way in which Kant expresses his conception of the double nature of the human being. Here I refer to his distinction between homo phaenomenon and bomo noumenon. The former expression refers to the human being as a sensible being, the latter to her existence as pure intelligence and as a being independent of sensible determinations and therefore free (cf. $M S$ 6:239). ${ }^{28}$ While these expressions might also have an ontological connotation, it seems reasonable to interpret them as marking a difference of aspects: these two bomines cannot but be one and the same human being. Now, for Kant, ignoring the noumenal aspect of ourselves, or the possible holiness and God-likeness of the rational being, equates to a deep self-misunderstanding. We might suffer from such a misunderstanding because our "pathologically determinable self" tries to make its claims "primary and originally valid, just as if it constituted our entire self" (KpV 5:74; cf. also Fakultäten 7:58). Interestingly, an immediate consequence of such unilateral self-comprehension is that we consider bomo noumenon as different from us and not as an aspect of ourselves, even though it is the reference point of our higher vocation, the ideal of how the human being, according to reason, should and can be (cf. MS-Vigilantius 27:593). To fail to view the bomo noumenon as an aspect of ourselves, as the subjective principle of legislation in the human being and thus indeed as our proper self, is to misunderstand ourselves.

However, there is another respect in which a sense of otherness with regard to bomo noumenon seems justified. After all, under this aspect the human being is a supersensible being, and therefore,

28. The distinction corresponds to that between "human being" and "humanity" in the Groundwork, and to that between "person" and "personality" in the Critique of Practical Reason. 
strictly speaking, unknowable. We thus encounter a question raised in a passage in Metaphysik $K_{3}$ with regard to moral self-legislation: we do not know whether there is a productive being in us that represents the law to us as an effect, or whether we ourselves possess this productive faculty - "We cannot explain what is working in us. Nevertheless its effects over sensible nature are astonishing" (Met$K_{3}$ 29:1023). ${ }^{29}$ In The Conflict of the Faculties, speaking of the inner supersensible principle by which the human being is determined to act, namely the representation of his duty, Kant maintains that "since we want to explain this principle, although we know no further ground for it, we represent it as a stimulus to good produced in us by God" (Fakultäten 7:43). He then writes that, "since the supersensible in us is inconceivable and yet practical, we can well excuse those who are led to consider it supernatural - that is, to regard it as the influence of another and higher spirit, something not within our power and not belonging to us as our own" (Fakultäten 7:59).

If a practical misunderstanding of ourselves according to which bomo phaenomenon is our whole self might lead us to neglect the supersensible in us, the incomprehensibility of this latter aspect of ourselves might lead us to consider it supernatural, as 'other' or 'above us', which is also a kind of misunderstanding. In fact, this shifting of the supersensible to a position 'above us' amounts to not having a clear image of our own nature and moral vocation, since bomo noumenon, while different from the human being as a sensible being, is, at least from a practical point of view, identical with him: as Kant in one occasion states, it is "the moral practical reason in us" that gives us laws (AA 23:398; cf. also MS 6:335). ${ }^{30}$ Kant might use the expression "God in us" to qualify moral practical reason or bomo noumenon as the source and place of the idea of holiness, and, in this sense, as our divine aspect.

To consider the morally-legislative reason in us as holy is to ascribe to it a divine property, and to the extent that we understand ourselves in relation to the moral law and its source within us, we

29. I owe the reference to this passage to G. SCHWARZ, Est Deus in nobis cit., 253.

30. Quoted in G. SCHWARZ, Ibidem, 262. 
might be said to have an experience of holiness in ourselves, or a kind of religious experience of ourselves. Obviously, as I have already noted, ascribing a divine property to reason might be a way to emphasize the superiority of its incentive relative to our subjective ends. However, this is not an objection to my reading, since the experience I am speaking of is identical to what Kant describes as the discovery of the sublimity of our supersensible existence, and since, as we have seen, we discover the sublimity of our existence in our experience of the overridingness of our own pure practical reason. More difficult, however, is the question whether Kant, in addition to the possibility of a religious experience of ourselves, also makes room for a religious experience in ourselves — namely whether he allows for the possibility that we not only consider our moral practical reason as divine but also somehow experience the divine in it.

A rather obvious way to support this possibility seems to be Kant's view of religion as "the recognition of our duties as divine commands" (KU 5:481; cf. also KpV 5:129). Religion, Kant claims, is "morals in relation to God as legislator" (KU 5:460) ${ }^{31}$ I cannot go into the details of this thesis here. ${ }^{32}$ Rather, I shall simply note that Kant might have had good reason to conceive of a consideration of our duties as divine commands. For one thing, although we have insight into their necessity, we also find it difficult to explain this necessity: "we cannot very well make obligation (moral constraint) intuitive for ourselves without thereby thinking of another's will, namely God's (of which reason in giving universal laws is only the spokesman)" (MS 6:487). Furthermore, we are not purely rational. Sometimes we are at variance with the laws of reason, and religion helps us to come to terms with this fact - a fact that, in light of Kant's conception of the vocation of human beings, might be inter-

31. Cf. also MS 6:440, where Kant states that, in the doctrine of virtue, the concept of religion is only "a principle of estimating all our duties as divine commands". As Förster notes, this modal 'as' will later turn out to be an 'as if'. See E. FörSTER, Kant's Final Synthesis cit.,143.

32. For interpretation cf. J. E. HARE, Kant on Recognizing our Duties as Divine Commands, "Faith and Philosophy" 17 (2000) 459-478, and above all P. KAIN, Interpreting Kant's Theory of Divine Commands, "Kantian Review" 9 (2005) 128149. 
preted as their irrational propensity not to (properly) be who they are or to neglect their supersensible being, their proper self.

However, Kant emphasizes that in considering our duties as divine commands we are expressing only "the relation of reason to the idea of God" which it makes for itself, and not to any being external to this idea (MS 6:487). ${ }^{33}$ He thereby seems to suggest that "God" refers not to any knowable entity, but to an idea that must necessarily be thought of in relation to moral action. God, Kant states in the Opus Postumum, in line with the more thoroughgoing idealism he was trying to develop, is not an object of experience but rather an idea (cf. Op. Post. 21:144). In light of this, one might doubt the correctness of describing the recognition of one's own duties as divine commands in terms of a religious experience. This doubt actually corresponds to Kant's own take on the matter. In The Conflict of the Faculties, Kant describes the example of a person who, having "experienced a change in himself" (in the sense of having new and better volitions) "which he does not know how to explain", traces his experience back to divine influence. Kant speaks against this kind of attribution, however; for him, "[ $t]$ o claim that we feel as such the immediate influence of God is self-contradictory, because the idea of God lies only in reason" (7:58). An objection along these lines might be made to someone who claims to experience her duties as divine commands.

My answer to this doubt, which ultimately concerns the independent existence of God, is simply that it does not necessarily exclude the religious character of the experience in question, if we take 'religious experience' to mean experience of something religiously significant. To view human duties "as if [they were] divine commands and in relation to a person", from which it would follow

33. Cf. also Op. Post. 22:122: "A universal, morally law-giving being, which, thus, has all power, is God. There exists a God, that is, one principle which, as substance, is morally law-giving". However, Kant adds that "it is not a substance outside myself, whose existence I postulate as a hypothetical being for the explanation of certain phenomena in the world". Actually, he seems to view the concept of duty as "contained identically in the concept of a divine being as an ideal" that human reason frames for the sake of its law-giving (Op. Post. 22:123). 
that "there is God in the soul of man" is a religiously significant experience, even if we cannot thereby "certify the existence of such a being: For the supersensible is not an object of possible experience" (Op. post. 22:120). ${ }^{34}$ However, I wish also to point out that if Kant refers to the idea of God in the passage just quoted, and therefore to a thought-entity or a subjective form, he also recognizes that reason as a practical faculty is somehow led to consider God as a being that exists outside of and independently of the subject. A striking example of this line of thinking in Kant is the following passage from the Opus Postumum: "A command, to which everyone must absolutely give obedience, is to be regarded by everyone as from a being which rules and governs over all. Such a being, as moral, however, is called God. So there is a God" (Op. Post. 22:127). ${ }^{35}$ From the point of view

34. Kant also notes that the divine being "requires no proof of its existence, as if it were a natural being; its existence already lies, rather, in the developed concept of this idea, according to the principle of identity: The mere form here counts to the being of the thing" (Op. Post. 21:92).

35. See E. FÖRSTER, Kant's Final Synthesis cit., 171-172 for a comment on this passage. The subtleties (and intricacies) of Kant's position are also evident in his discussion of conscience. He claims that the concept of God as a moral being that has the power to give effect to his laws "is always contained (even if only in an obscure way) in the moral self-awareness of conscience". However, he maintains that this does not mean that we are "entitled", through the idea to which our conscience "unavoidably" guides us, "to assume that such a supreme being actually exists" outside ourselves (MS 6:439). The idea of God is not given to us "objectively, by theoretical reason", namely it is not a content of knowledge; rather, it is given to us "only subjectively, by practical reason, putting itself under obligation to act in keeping with this idea" (MS 6:639-640). Kant shifts between identifying God with our pure practical reason - a perspective that he repeatedly appeals to in the last phase of his thought (cf. Op. Post. 21:25-26 and 145) - and the idea of a (practical) commitment to his independent existence. Let us consider, for example, his claim that, through using practical reason, human beings are led to think of conscientiousness - which, he recalls, is also named religio - "as accountability to a holy being (morally lawgiving reason) distinct from us yet present in our inmost being" (MS 6:440). As nuanced as this position might be, it is barely tenable. How can our morally lawgiving reason really be distinct from us if it is our proper self? And, if it is not, can Kant really be satisfied with a relation to a subjectively-given idea (of God)? Maybe there is a problem here. Laws should not only be promulgated, but also enforced (or enforceable), which here refers to the wielding of sanctions against law-breakers. But one cannot punish oneself for breaking the laws one gives oneself. Self-punishment is a contradiction (cf. MS 6:485). Of course, we can feel guilty; but is guilt a sanction, given that it is not deliberately imposed (on us) as sanctions are? The strategy of dividing 
of a genuine assertion of existence, respect for the law or consciousness of one's duty (cf. MS 6:464) could be a religious experience of God as an independent being. This is not to say that people, in conceiving their own duties as divine commands, somehow perceive God's act of commanding. Presumably, the sense of being commanded by God relates to the way one feels in being obliged to obey a moral rule. The perceptual element described above (the perception of an act of command) does not seem essential to this experience, at least if what is really at stake is the effect of being commanded. ${ }^{36}$ Provided one has a concept of God, one may "hear" the (metaphorical) voice of reason as the (metaphorical) voice of God. The tricky point is then to show how the experience can reveal that it is God who commands. How can one rationally believe that it is God who commands a duty? Maintaining his conviction that morality (possibly) leads to religion and not the other way round, Kant's answer is that we regard certain moral rules as divine commands "because we are internally obligated to them" (KrV A819/B847).

With this standard in place, Kant might well allow that the moral feeling can be expanded (or deepened) into a religious experience. In understanding herself in relation to the holiness of her pure will, a person might have a religious experience of herself, conceiving of her duties as divine commands, whilst also in a sense experiencing God in herself - in her personality. I will conclude these reflections with a couple of remarks on moral autonomy and divine commands.

\section{CONCLUDING REMARKs}

In this paper, we have seen that Kant conceives of the vocation of human beings in terms of (moral) self-legislation. I have argued that

the self into parts or aspects and arguing that the rational self has power over the sensible self, such that it can limit its claims, restrain it, and legislate over it, might appear to be a mere metaphor, since it is not actual different selves that recreate the relation between subjects. Kant is well aware of the problem: "We cannot very well make obligation (moral constraint) intuitive for ourselves without thereby thinking of another's will, namely God's" (MS 6:487).

36. Here I have modified an example by R. AUDI, Rationality cit., 109. 
in conceiving of our vocation in this way, Kant makes room for the idea of something holy in us, or of a God in us. Though this might only be a way of representing our pure practical reason and its law to ourselves, nothing prevents us from taking Kant's words literally. Both interpretations are possible; namely, we can suppose that Kant views pure practical reason (or its law) as God in us, but we can also read him as suggesting that we might have a kind of experience of God to the degree that we experience the commands of pure practical reason as His commands. If we read Kant this way, conceiving our duties as divine commands might involve a relational religious experience of God (as legislator). Whether this experience is really of something divine or as of something divine might in the end be left unanswered, however. Either conception is possible, and Kant leaves room for both interpretations.

Is the conception of our duties as divine commands in the stronger, literal (and not merely metaphorical) sense compatible with moral autonomy? I think it is, because the duties that we recognise as divine commands are precisely those that pure practical reason autonomously imposes on us as rational beings. To conceive of them as divine commands is not to relinquish moral autonomy, since to conceive of their obligating force as deriving from God's will is to conceive of it as deriving from a supremely rational being who wills "what all rational beings will" ${ }^{37}$ One can conceive of duties in this way and still hold fast to the Kantian claim that our ability to recognize our duties and to act accordingly depends neither on the idea "of another being above" human beings nor on an incentive beyond the moral law itself ( $R G V$ 6:3). We arrive at the same conclusion even if we subscribe to a stronger version of the divine command view, according to which what is obligatory is such because God commands it (cf. Op. Post. 22:127). God's commands are not arbitrary. Indeed, it is part of the Kantian concept of God that $\mathrm{He}$ is a moral legislator; therefore, what He commands reflects what a pure will wants. ${ }^{38}$ While the property of being a duty might be

37. A. W. Moore, Noble in Reason, Infinite in Faculty cit., 149-150.

38. "Religion is the recognition of all duties as divine commands, not as sanctions, 
conceived as identical with that of being commanded by God, conceiving a duty as a divine command does not turn the concept of the obligatory into a theological concept. One can know that something is a duty without conceiving it as a divine command. Kant's view is that a type of action is divinely commanded on the same grounds that make it a duty for us. Moral autonomy is therefore compatible with experiencing a duty as a divine command. This religious experience in ourselves in truth involves a deepened religious experience of ourselves.

i.e., arbitrary and contingent ordinances of a foreign will, but as essential laws of any free will as such" (KpV 5:129). 



\section{NOVEDADES \\ BIBLIOGRÁFICAS \\ BOOKS RECEIVED}

Se incluyen aquí los libros de filosofía enviados por las editoriales o los autores a la Redacción de Anuario Filosófico, sin que esto excluya una noticia más amplia en la sección de Reseñas. Para facilitar la consulta de este elenco, los libros están distribuidos por grandes áreas temáticas y, dentro de cada área, por orden alfabético.

\section{HISTORIA DE LA FILOSOFÍA}

\section{GENERAL}

Bangert, K.; Und sie drecht sich doch; 50 Antworten auf die Frage, wie alles begann, Theiss, WBG, Darmstadt, 2015, 383 pp.

Bruun, O.; Feng shui. Una introducción, Siglo XXI, Madrid, 2015, 252 pp. Decher, F.; Handbuch der Philosophie des Geistes, WBG-Wissenschaftliche Buchgeselschat, Darmstdt, 2015, 302 pp.

\section{ANTIGUA Y ORIENTAL}

Gambra, J. M.; Oriol, M.; Lógica aristotélica, 2a ed., Dykinson, Madrid, 329 pp.

Martino, F. de; Morenilla, C. (eds.); En el umbral de la obra. Personajes y situaciones en el prólogo. Teatro y sociedad en la antigüedad clásica, Levante, Bari, 2015, 461 pp.

Politis, V.; The Structure of Enquiry in Plato's Early Dialogues, Cambridge University Press, Cambridge, 2015, 255 pp.

Ros, G.; Langermann, Y. T.; The Alexandrian Summaries of Galen's 'On Critical Days'. Editions and Translations of the two Versions of the 'Fawami', Brill, Leiden, 2015, $151 \mathrm{pp}$.

Teofrasto, Caracteres, Rialp, Madrid, 2015, 84 pp. 


\section{MEDIEVAL Y PATRÍSTICA}

Amrán, R.; Fudíos y conversos en las crónicas de los reyes de Castilla (siglos XIII al XVI), Dykinson, Madrid, 2015, 137 pp.

Anónimo, The Notory Art of Shorthand (Ars notoria notarie). A Curious Chapter in the History of Writing in the West, Haines, J. (ed.); Peeters, Leuven, 2015, 190 pp.

Aquinas, T.; De unione Verbi incarnate, Nutt, R. W. (ed.), Peeters, Leuven, 2015, $157 \mathrm{pp}$.

Dupont, A.; Gaumer, M. A.; Lamberigs M. (eds.); The Uniquely African Controversy. Studies on Donatist Christianity, Peeters, Leuven, 2015, 388 pp.

Durandi de Sancto Porciano; Scriptum Super IV Libros Sententiarum. Distinctiones 1-7 libri Quarti, Speer, A.; Guldentops, G.; Pellegrino; G. (eds.); Peeters, Leuven, 2015, 219 pp.

Durandi de Sancto Porciano; Scriptum Super IV Libros Sententiarum. Distinctiones 39-44 libri Secundi, Speer, A., Perrone, M. (eds.); Peeters, Leuven, 2014, 177 pp.

Elgrably-Berzin, G.; Avicena in Medieval Hebrew Traslation. Todrosi's Translation of Kitab Al-Najat, on Psychology and Metaphysics, Brill, Leiden, 2015, 223 pp.

Fidora, A. (Hg.); Die mantische Künste und die Epistemologie prognosticher Wissnschaften im Mittelalter, Böhlau, Köln, 2013, 208 pp.

Goris, H.; Hendriks, L.; Schoot, H. (eds.); Faith, Hope and Love. Thomas Aquinas on Living by the Theological Virtues, Peeters, Leuven, 2015, 308 pp.

Kahl, O.; The Sanskrit, Syriac and Persian Sources in the 'Comprehensive Book' of Rhazes, Brill, Leiden, 2015, 487 pp.

O'Reilly, K. E.; The Hermeneutic of Knowing and Willing in the Thought of St. Thomas Aquinas, Peeters, Leuven, 2013, 309 pp. Speer, A.; Retucci, F.; Jeschke, T.; Guldentops, G. (eds.); Durand of Saint-Pourcain and His 'Sentences' Comentary. Historical, Philosophical, and Theological Issues, Peeters, Leuven, 2014, $434 \mathrm{pp}$.

\section{RENACIMIENTO Y HUMANISMO, SIGLOS XV Y XVI}

Galán, I.; El Castillo: Teresa de fesús ante Kafka. (La genial inculta y 
alegre frente al culto genio amargado), Dykinson, Madrid, 2015, $134 \mathrm{pp}$.

García Benítez, A.; La orilla de las eternas miradas. Fuan de Castellanos o el triunfo de la tenacidad, Alfar, Sevilla, 2015, 355 pp.

Owen, J. J.; Making Religion Safe for Democracy. Transformation from Hobbes to Tocqueville, Cambridge University Press, Cambridge, 2015, 164 pp.

Pasqua, H. (ed.); Nicolas de Cues et l'Islam, Peeters, Leuven, 2013, $202 \mathrm{pp}$.

\section{SIGLOS XVII Y XVIII}

Bourke, R.; Empire and Revolution. The Political Life of Edmund Burke, Princeton University Press, Princeton, 2015, 1001 pp.

Doran, R.; The Theory of the Sublime. From Longinus to Kant, Cambridge University Press, Cambridge, 2015, 311 pp.

Ferri-Benedetti, F.; El hilo de Hipsípila: Metastasio y la tradición clásica, Levante, Bari, 2015, 335 pp.

Holz, H. H.; Leibniz in der Rezeption der klassischen deutschen Philosophie, Zimmer, J. (Hg.); WBG-Wissenschaftliche Buchgesellschaft, Darmstadt, 2015, 206 pp.

Klein, U.; Humboldts Preussen. Wissenschaft und Technik in Aufbruch, WBG-Wissenschaftliche Buchgeselschat, Darmstdt, 2015, 336 pp.

Miller, J.; Spinoza and the Stoics, Cambridge University Press, Cambridge, 2015, $238 \mathrm{pp}$.

Raedler, S.; Kant and the Interest of Reason, De Gruyter, Berlin, 2015, $275 \mathrm{pp}$.

\section{CONTEMPORÁNEA}

Siglo XIX

Alznauer, M.; Hegel's Theory of Responsibility, Cambridge University Press, Cambridge, 2015, 218 pp.

Bensussan, G.; Les âges du monde de Schelling. Une traduction de l'absolu, Vrin, Paris, 2015, 244 pp.

Brentano, F.; La psicología de Aristóteles con especial atención a la doctrina del entendimiento agente. Seguida de un apéndice sobre la acti- 
vidad del Dios aristotélico, Torrijos Castrillejo, D. (ed.); Universidad San Dámaso, Madrid, 2015, 334 pp.

Conway, D. (ed.); Kierkegaard's 'Fear and Trembling'. A Critical Guide, Cambridge University Press, Cambridge, 2015, 278 pp. Giusti, M. (ed.); Dimensiones de la libertad. Sobre la actualidad de la ' $F i$ losofía del derecho' de Hegel, Anthropos, Barcelona, 2015, 286 pp.

Hegel, Georg Wilhelm Friedrich; Ausgewäblte Werke. Band I: Phänomenologie des Geistes; BadII: Wissenschaft der Logik, I-II; Band III: Grundlinien der Philosophie des Rechts; Band IV: Enzyclopädie der philosophischen Wissenschaften, I-II; Band V: Enzyklopädie der philosophischen Wissenschaften, III, WBG-Wissenschaftliche Buchgesellschaft, Darmstadt, 2015, 612, 456+575, 531, $393+539,432$ pp.

Kreines, J.; Reason in the Word. Hegel's Metaphysics and Its Philosophical Appeal, Oxford University Press, Oxford, 2015, 290 pp.

Ottonello, P. P.; Il nichilismo europeo. Vol. I: Saggi introductivo. Vol. II: Lutero, Kierkegaard; Vol. III: Nietzsche, Heidegger, Marsilio, Venezia, 2015, 158, 118, 104 pp.

Siep, L.; El camino de la fenomenología del espíritu. Un comentario al 'Escrito sobre la diferencia' y la 'Fenomenología del Espiritu' de Hegel, Anthropos, Barcelona, 2015, 333 pp.

Warren, N. de; Staiti, A. (eds.); New Approaches to Neo-Kantianism, Cambridge University Press, Cambridge, 2015, 322 pp.

\section{Siglos XX: hasta 1968}

Anderson, C. B.; McCormack, B. L. (eds.); Karl Barth and the Making of Evangelical Theology. A Fifty-Year Perspective, Willian B. Eerdmans, Grand Rapids (MI), 2015, 237 pp.

Benjamin, Walter; Ausgewählte Werke; Band I: Abhandlungen; Band II: Anhandlungen, Autobiographische Schriften, Aus dem PassagenWerk; Band III: Aufsätze, Essays, Vorträge; Band IV: Kritiken, Rezensionen, Essays; Band V: Fragmente, kleine Prosa, WBGWissenschaftliche Buchgesellschaft, Darmstadt, 2015, 639, 744, 737, 655, 688 pp.

Berstein, R. J.; Violencia. Pensar sin barandillas, Gedisa, Barcelona, 2015, 285 pp. 
Capograssi, G.; El individuo sin individualidad, Encuentro, Madrid, 2015, 92 pp.

Coriando, P-L.; Röck, T.; Perspektiven der Metaphysik im "postmetaphysichen" Zeialter, Duncker und Humblot, Berlin, 2015, 177 pp.

Kim, H. Y.; Sorge und Geschichte. Phänomenologische Untursuchung im Anschluss an Heidegger, Duncker und Humblot, Berlin, 2015, $187 \mathrm{pp}$.

Messinese, L.; Heideggers Kritik der abenlándischen Logik und Metaphysik. Ein kritischer Dialog, Duncker und Humblot, Berlin, 2015, 107 pp.

Porto Ucha, A. S.; Vázquez Ramil, R.; María de Maeztu. Una antología de textos, Dykinson, Madrid, 2015, 311 pp.

Reiner, H.; Fundamentos, principios y normas particulares del derecho natural, Encuentro, Madrid, 2015, 65 pp.

Trawny, P.; Heidegger y el mito de la conspiración mundial de los judios, Herder, Barcelona, 2015, 172 pp.

Morris, M.; El "Tractatus" de Wittgenstein. Guía de lectura, Cátedra, Madrid, 2015, 387 pp.

\section{Siglos XX: desde 1968}

Horujy, S. S.; Practices of the Self and Spiritual Practices. Michel Foucault and the Easter Christian Discourse, Willian B. Eerdmans, Grand Rapids (MI), 2015, 181 pp.

Millán Puelles, Antonio; Obras completas. VII. Léxico filosófico (1984), Asociación de Filosofía y Ciencia Contemporánea, Rialp, Madrid, 2015, 634 pp.

Guitton, J.; Pablo VI secreto, Encuentro, Madrid, 2015, 159 pp.

Mandle, J.; Reidy, D. A.; The Cambridge Rawls Lexicon, Cambridge University Press, Cambridge, 2015, 897 pp.

Löser, W.; Geschenkte Wabheit. Annäherungen an das Werk Hans Urs von Balthasars, Echter, Würzburg, 2015, 349 pp.

\section{Siglo XXI}

Aguirre Oraa, J. M. (ed.); Retos y perspectivas de la filosofía para el siglo XXI, Anthropos, Barcelona, 2015, 396 pp. 
Burgos, J. M. (ed.); España vista por sus intelectuales, Palabra, Madrid, 2015, 265 pp.

Bustos, J.; La granja bumana. Fábulas para el siglo XXI, Ariel, Madrid, 2015, 283 pp.

Curtis, W. M.; Defending Rorty. Pragmatism and Liberal Virtue, Cambridge University Press, Cambridge, 2015, 286 pp.

Josa, P. F. R.; La gran revolución americana. Raíces ideológicas de la política exterior de Estados Unidos, Encuentro, Madrid, 2015, 316 pp.

Volk, C.; Arendtian Constitutionalism. Law, Politics and the Order of Freedom, Bloomsbury, Hart, Oxford, 2015, 284 pp.

\section{FILOSOFÍA SISTEMÁTICA}

\section{INTRODUCCIÓN A LA FILOSOFÍA}

Cox, G.; Wie werde ich Philosoph? Oder Wir man fast sicher sein kann, das fast nich sicher ist, Theiss, WBG, Darmstadt, 2015, 172 pp.

Simon, C.; Warten eine Philosophie macht der Sebnsucht glücklich; Theiss, WBG, Darmstadt, 2015, 192 pp.

\section{LÓGICA Y FILOSOFÍA DEL LENGUAJE}

Frankfurt, H. G.; On Bullshit, Princeton University Press, Princeton, 2015, $67 \mathrm{pp}$.

Masson, R.; Without Metaphor, No Saving God. Theology After Cognitive Linguistic, Peeters, Leuven, 2014, 331 pp.

Tindale, C. W.; The Philosophy of Argument and Audiences Reception, Cambridge University Press, Cambridge, 2015, 244 pp.

\section{FILOSOFÍA DE LA MATEMÁTICA, INTELIGENCIA ARTIFICIAL Y CIENCIAS DE LA COMPUTACIÓN}

Horgan, T.; Sabatés, M.; Sosa, D. (eds.); Qualia and Mental Causation in a Physical World. Themes from the Philosophy of Jaegwon Kim, Cambridge University Press, Cambridge, 2015, 271 pp. Peterson, M. (ed.); The Prisoner's Dilemma, Cambridge University Press, Cambridge, 2015, 298 pp. 
FILOSOFÍA DE LA NATURALEZA, DE LA BIOLOGÍA Y DE LA CIENCIA Hadot, P.; El velo de Isis. Ensayo sobre la historia de la idea de la naturaleza, Alpha Decay, Barcelona, 2015, 415 pp.

Hailwood, S.; Alienation and Nature in Environmental Philosophy, Cambridge University Press, Cambridge, 2015, 266 pp.

Vanney, C. E.; Lombardi, O. (eds.); Fronteras del determinismo científico. Filosofía y ciencia en diálogo, Biblioteca Nueva, Madrid, 2015, 237 pp.

Weirich, P.; Models of Decision-Making. Simplifying Choices, Cambridge University Press, Cambridge, 2015, 263 pp.

\section{GNOSEOLOGÍA, EPISTEMOLOGÍA Y NEUROCIENCIA.}

Armour-Garb, B.; Woodbridge, J. A.; Pretence and Pathology. Philo-

sophical Factionalism and its Applications, Cambridge University Press, Cambridge, 2015, 273 pp.

Baer, J.; Rother, W. (Hg.); Vertrauen, Schwabe, Basel, 2015, 231 pp. Davidson, D.; Verdad y predicación, Alpha Decay, Barcelona, 2015, $253 \mathrm{pp}$.

Galluzo, G.; Loux, M. J.; The Problems of Universal in Contemporary Philosophy, Cambridge University Press, Cambridge, 2015, 229 pp.

Goldberg, S. C. (ed.); Externalism, Self-Knowledge, and Skepticism. New Essays, Cambridge University Press, Cambridge, 2015, $263 \mathrm{pp}$.

O'Hear, A. (ed.); Mind, Self and Person, Royal Institute of Philosophy Supplement: 76, Cambridge University Press, Cambridge, 2015, 330 pp.

\section{METAFÍSICA GENERAL Y ONTOLOGÍA}

Kärkkäinen, V-M.; Creation and Humanity, Vol 3, Willian B. Eerdmans, Grand Rapids (MI), 2015, 554 pp.

Segalerba, G.; Semantik und Ontologie, Drei Studien zu Aristoteles, Peter Lang, Bern, 2015, 547 pp.

\section{TEODICEA Y FILOSOFÍA DE LA RELIGIÓN}

Forcades i Vila, T.; La teología feminista en la bistoria, Fragmenta, Barcelona, $2014\left(2^{\mathrm{a}}\right), 141 \mathrm{pp}$. 
Gnau, D.; Person werden. Zu Wesen und Benstimmung des Menchen in der Theologie von Panagolis Nellas, Christos Yannaras und Ioannis Zizioulas, Echter, Würzburg, 2015, 304 pp.

Greenway, W.; For the Love of All Creatures. The Story of Grace in Genesis, William B. Eerdmanns, Grand Rapids (MI), 2015, 162 pp.

Hauervas, Stanley; The Work of Theology, William B. Eerdmans, Grand Rapids (MI), 2015, 293 pp.

Schindler, D.; Healy, N. J. Jr.; Freedom, Truth, and Human Dignity. The Second Vatican Council's Declaration on Religious Freedom, William B. Eerdmans, Grand Rapids (MI), 2015, 477 pp.

\section{ANTROPOLOGÍA Y PSICOLOGÍA FILOSÓFICA}

AA. VV. Quién. Revista de Filosofía Personalista, Asociación Española de Personalismo, $\mathrm{n}^{\circ}$ 1, 2015, $193 \mathrm{pp}$.

Braidotti, R.; Lo Posthumano, Gedisa, Barcelona, 2015, 253 pp.

Cortina, A.; Serra, M-A.; ¿Humanos o posthumanos? Singularidad tecnológica y mejoramiento bumano, Fragmenta, Barcelona, 2015, $525 \mathrm{pp}$.

González de Chávez Fernández, M.A.; Mujeres y hombres, identidad y conflictos. Feminidad, masculinidad y orden simbólico: el porqué del desencuentro entre sexos, Biblioteca Nueva, Madrid, 2015, 358 pp.

Han, B-C.; El aroma del tiempo. Un ensayo filosófico sobre el arte de demorarse, Herder, Barcelona, 2015, 163 pp.

Miguel, A. de; Neoliberalismo sexual. El mito de la libre elección. Feminismos, Universidad de Valencia, Cátedra, Madrid, 2015, 351 pp.

\section{FILOSOFÍA DE LA HISTORIA, DE LAS CIENCIAS HUMANAS Y DE LA RAZÓN PRÁCTICA}

Sáez Rueda, L.; El ocaso de Occidente, Herder, Barcelona, 2015, 413 pp.

Schmidt, I.; Nach dem Nationalsozialismus. Die TH Darmstadt zwischen Vergangenbeitspolitik und Zukunftsmanagement (19451960), WBG-Wissenschaftliche Buchgeselschaft, Darmstadt, 2015, 562 pp. 
Wallraff, M. (Hg.); Geschichte als Argument? Historiograophie und Apologetik, Peeters, Leuven, 2015, 285 pp.

\section{ÉTICA Y AXIOLOGÍA}

Camosy, C. C.; Beyond the Abortion Wars. A Way Forward for a New Generation, Willian B. Eerdmans, Grand Rapids (MI), 2015. 207 pp.

Ferrer Santos, U.; Acción, deber, donación. Dos dimensiones éticas inseparables de la acción, Dykinson, Madrid, 2015, 219 pp.

May, L.; Contingent Pacifism. Revisiting Fust War Theory, Cambridge University Press, Cambridge, 2015, 272 pp.

Ogien, R.; Human Kindness and the Smell of Warm Croissants. An Introduction to Ethics, Columbia University Press, New York, 2015, 224 pp.

\section{FILOSOFÍA SOCIAL Y SOCIOLOGÍA}

Capograssi, G.; El individuo sin individualidad, Encuentro, Madrid, 2015, 92 pp.

Hunyadi, M.; La tiranía de los modos de vida. Sobre la paradoja moral de nuestro tiempo, Cátedra, Madrid, 2015, 116 pp.

Melloni, J.; Hacia un tiempo de sintesis, Fragmenta, Barcelona, 2015, $264 \mathrm{pp}$.

\section{FILOSOFÍA DE LA ECONOMÍA}

González H. F.; ¿Por qué creer en España? Los siete atributos de la marca pais, Alfar, Sevilla, 2015, 107 pp.

Hirschman, A. O.; Más allá de la economía. Antología de ensayos, Woldenberg, J. (ed.); FCE-Fondo de Cultura Económica, México, 2014, 519 pp.

Piketty, T., El capital en el siglo XXI, FCE-Fondo de Cultura Económica, México, 2014, 663 pp.

\section{FILOSOFÍA POLÍTICA}

Jackson, T. P.; Political Agape. Christian Love and Liberal Democracy,

William B. Eerdmans, Grand Rapids (MI), 2015, 427 pp.

Olthuis, G.; Kohlen, H.; Heier, J.; Moral Boundaries Redrawn. The 
significance of Joan Tronto's Argument for Political Theory, Professional Ethics, and Care as Practice, Peeters, Leuven, 2014, 232 pp.

Ortí Bordás, J. M.; Desafección, posdemocracia, antipolítica, Encuentro, Madrid, 2015, $223 \mathrm{pp}$.

Pallmall, A. O.; Globalización y gobierno global, Alfar, Sevilla, 2015, $547 \mathrm{pp}$.

Pradera, J.; La transición española y la democracia, Estefanía, J. (ed.); FCE-Fondo de Cultura Económica, México, 2014, 164 pp.

Sedmak, C. (Hrsg.); Gerechtigkeit. Vom Wert der Verbältnismässigkeit, WBG-Wissenschaftliche Buchgeselschaft, Darmstadt, 2015, $284 \mathrm{pp}$.

\section{FILOSOFÍA JURÍDICA}

Frankfurt, Harry G.; Inequality, Princeton University Press, Princeton, 2015, $101 \mathrm{pp}$.

Ibáñez, P. A.; Tercero en discordia. Furisdicción y juez del estado constitucional, Trotta, Madrid, 2015, 556 pp.

\section{ESTÉTICA, FILOSOFÍA DEL ARTE Y TEORÍA LITERARÍA}

AA. VV.; Quaderni dell'Orazio Flecco', Levante, Bari, 2015, 248 pp.

AA. VV.; Il mio cuore, la mia terra, la mia vita. Antologia di Poesie in Vernaloco Pugliese. X edizione 2014-2015, Levante, Bari, 2015, $539 \mathrm{pp}$.

Allen, J. J.; Finch, P. S.; Don Quijote en el arte y pensamiento de Occidente, Cátedra, Madrid, 2015, 247 pp.

Escudero, S.; Abbie, Alfar, Sevilla, 2015, 124 pp.

Gómez Vázquez, J.; Diario sin días, Alfar, Sevilla, 2015, 142 pp.

Kitcher, P.; Muertes en Venecia. Las posibles vidas de Gustav von Archenbach, Cátedra, Madrid, 2015, 287 pp.

Lanchester, J.; Capital, Anagrama, Barcelona, 2015, 597 pp.

Llano, A. (ed.); El arte más allá de sí mismo. Aproximaciones a la cultura artística contemporánea, Biblioteca Nueva, Madrid, 2015, 253 pp.

Murciano, C.; De roble y seda, Encuentro, Madrid, 2015, 63 pp.

Pizzo Russo, L.; Psicologia delle Arte, Russo, L. (ed.); Supplementa 
31, Settembre 2015, Aesthetica, Universita degli Studi, Palermo, $382 \mathrm{pp}$.

Zweig, S.; El misterio de la creación artística, Rialp, Madrid, 2015, 95 pp.

\section{FILOSOFÍA DE LA CULTURA Y DE LOS MEDIOS DE COMUNICACIÓN} Feuchtwanger-Sarig, N.; Irbving, M.; Schrijver, E. (eds.); Jewish Art in Context: The Role and Meaning of Artefacts and Visual Images, Peeters, Leuven, 2014, 165 pp.

Krumeich, G.; Deutschland, Frankreich un der Krieg. Historische Studien zu Politik, Militär und Kultur, Klartext, Essen, 2015, 484 pp.

Mischke, J.; Familiennamen im mittelalterlichen Basel. Kulturhistorische Studien zu ibrer Entstehung und zeitgenössischen Bedeutug, Schwabe, Basel, 2015, 421 pp.

\section{FILOSOFÍA DE LA EDUCACIÓN}

Kitson, A.; Steward, S.; Husbands, C.; Didáctica de la historia en Secundaria Obligatoria y Bachillerato, Morata, Madrid, 2015, 255 pp.

\section{FILOSOFÍA DE LAS INSTITUCIONES}

AA. VV.; Risorgimento e Mezzogiorno, Rasegna di Sudi Storici, Anno XXIV, n. 49-50, Dicembre 2014, Levante, Bari, 335 pp.

Bizarro, R. et al.; Bari cosi. Personagi, Levante, Bari, 2015, 156 pp. 


\section{ESTADÍSTICA DE ACEPTACIÓN 2015 STATISTICS 2015}

Anuario Filosófico publica tres números al año, de los que generalmente dos son de carácter monográfico (con un Editor Asociado) y el tercero es misceláneo. En el número misceláneo se publican artículos que la revista recibe por iniciativa de sus autores, después de superar el proceso de evaluación. En los números monográficos, los artículos llegan a la revista por petición del Editor Asociado. Los artículos de los números monográficos son sometidos al mismo proceso de evaluación que los del número misceláneo.

\begin{tabular}{lrrr} 
& MONOGRÁFICOS & MISCELÁNEO & \multicolumn{1}{c}{ TOTAL } \\
RECIBIDOS & $12(100 \%)$ & $43(100 \%)$ & $55(100 \%)$ \\
RECHAZADOS & $2(17 \%)$ & $33(77 \%)$ & $35(64 \%)$ \\
ACEPTADOS & $10(83 \%)$ & $9(21 \%)$ & $19(34 \%)$ \\
SUPEDITADOS A MEJORAS & $0(0 \%)$ & $1(2 \%)$ & $1(2 \%)$
\end{tabular}




\section{NORMAS PARA AUTORES INSTRUCTIONS FOR AUTHORS}

1. Todos los escritos que se envíen para su publicación en Anuario Filosófico, tanto artículos como reseñas, deben ser completamente inéditos. Mientras están en proceso de evaluación o de edición, no deberán remitirse a ninguna otra publicación. Una vez hayan sido publicados, los autores podrán utilizar sus textos con total libertad, aunque citando siempre su publicación original en Anuario Filosófico.

2. Los artículos y las reseñas bibliográficas estarán escritos en castellano o en inglés. La Redacción se reserva el derecho de aceptar textos enviados en otras lenguas, teniendo en vista la situación general del volumen.

\section{Normas para los artículos}

3. Los artículos originales han de ser enviados en un formato habitual y fácilmente editable — como Word o RTF — al Dr. Manuel Cruz (articulosaf@unav.es). Se enviarán dos versiones. En una de ellas, para facilitar su revisión anónima, el autor debe eliminar toda referencia en el artículo a otras obras y artículos escritos por él mismo - tanto en el cuerpo como en las notas-, o hacerlo de forma que no revele su propia autoría. También deberá omitir la mención a reconocimientos de su participación en proyectos financiados y otros agradecimientos.

4. Los artículos se someterán a una doble revisión anónima por expertos ajenos al Consejo de Redacción. Se valorarán: el interés del tema; la profundidad e innovación en su tratamiento; el conocimiento del estado de la cuestión; el diálogo con la bibliografía más relevante y actualizada; la unidad, claridad, coherencia, equidad y rigor de la argumentación; la adecuación del título, del resumen y de las palabras clave; la extensión proporcionada del texto y de las notas; y la elegancia formal y literaria.

5. En un plazo habitual de dos meses y medio, y máximo de seis, el Consejo de Redacción comunicará la aceptación o rechazo de un artículo, junto con las observaciones o sugerencias emitidas por los evaluadores. En el mes de junio, el Consejo de Redacción selecciona, de entre todos los artículos aceptados, cuáles se incluirán en el número misceláneo que se publica en diciembre de cada año e informarán de ello a los autores correspondientes. 
6. Los autores de artículos en vía de publicación recibirán la prueba del texto tras ser compuesto tipográficamente, para su inmediata corrección. Una vez publicado, recibirán gratuitamente un ejemplar del correspondiente número de Anuario Filosófico y la separata electrónica de su artículo.

\section{Formato de los artículos}

7. Los artículos tendrán una extensión máxima —incluidas las notas— de 8.000 palabras (unos 50.000 caracteres con espacios). Este número de palabras, o de caracteres, puede calcularse fácilmente en los programas informáticos de tratamiento de textos.

8. En la primera página deben figurar el nombre del autor, la institución académica en la que trabaja (departamento, facultad y universidad, o sus análogos), la dirección postal (código postal, ciudad y país) y el correo electrónico. También deben incluirse, en español y en inglés: el título del artículo, un resumen de 75 palabras como máximo, y unas 4 palabras clave.

9. Para facilitar la composición, el texto debe introducirse sin ningún formato ni estilo de fuente. Los subtítulos han de estar numerados secuencialmente, así: 1. 2. 3., etc. Los títulos de posteriores subdivisiones deben seguir una ordenación alfabética, así:

a) b) c), etc. Por ejemplo:

4. Los últimos comentarios de Tomás de Aquino a Aristóteles

a) El comentario al "De caelo"

10. Las notas a pie de página han de ser concisas. Las citas en el cuerpo del texto también serán breves, y han de ir entrecomilladas: "así". Si superan las tres líneas, deberán ir en párrafo aparte. Para introducir un término explicativo dentro de una cita se usarán corchetes, como en el siguiente ejemplo: "La vinculación de ésta [situación especial] al fin del agente".

11. Las referencias bibliográficas siempre deben ir a pie de página, y nunca en una bibliografía final ni en el cuerpo del texto. Deben tener el siguiente formato:

Para libros: L. Polo, Curso de Teoría del conocimiento, vol. 4/1 (Eunsa, Pamplona, 1994); R. Spaemann, Etica: cuestiones fundamentales (Eunsa, Pamplona, 1987) 113-115.

Para colaboraciones en obras colectivas: A. FuERTES, El argumento cosmológico, en A. L. GonZÁlez (ed.), Las pruebas del absoluto según Leibniz (Eunsa, Pamplona, 1996) 47-158.

Para artículos: R. Yepes, Los sentidos del acto en Aristóteles, "Anuario Filosófico" 25/3 (1992) 493-512.

Para números monográficos de revista: A. M. GonZÁLEZ, R. LÁZARo (eds.), Razón práctica en la Ilustración escocesa. Número monográfico: "Anuario Filosófico" 42/1 (2009) 1-257.

12. Pueden usarse referencias abreviadas en los siguientes casos:

Cuando de un mismo autor se cite una sola obra, se abreviará su título así: R. SPaEMANN, op. cit., 108. 
Si de un mismo autor hay que citar más de una obra, se reiterará el título de forma abreviada; por ejemplo: R. Spaemann, Lo natural cit., 15; L. Polo, Curso cit., vol. 4/1, 95 .

Puede utilizarse "Ibidem" cuando se repita una misma referencia consecutivamente.

13. Para garantizar la correcta transcripción de los textos en griego, deberán estar escritos con la fuente Gentium Plus, disponible gratuitamente para Windows, Mac y Linux Debian/Ubuntu en la siguiente dirección:

http://scripts.sil.org/cms/scripts/page.php?site_id=nrsi\&item_id=Gentium_download

Si se necesita usar caracteres de otras lenguas no incluidos en dicha fuente, será preceptivo emplear una fuente Unicode. Al enviar la versión final de un manuscrito con fuentes no latinas, deberá adjuntarse también una copia en pdf del documento, que permita cotejar la transcripción.

\section{Normas para las reseñas bibliográficas}

14. Cada reseña debe tener entre 600 y 1.200 palabras, y ser completamente original e inédita.

15. Salvo casos excepcionales, no se aceptarán reseñas de libros con más de tres años de antigüedad. Las obras recensionadas han de ser primeras ediciones, o bien reediciones con modificaciones sustantivas.

16. Para evitar conflictos de intereses, es preferible que no estén escritas por personas cercanas al autor del libro recensionado o que hayan colaborado en su edición o diseño. $\mathrm{El}$ autor de un libro recensionado no debe tener ascendiente profesional sobre el autor de la reseña, como es el caso de un director de tesis o de un miembro del mismo grupo de investigación.

17. Si es preciso incluir alguna cita diferente a la del libro que se está reseñando, se hará en el cuerpo del texto, entre paréntesis, siguiendo lo que se indica en los nn. 11 y 12. Si la cita es del libro que se está reseñando, basta con incluir el número de página, así: (p. 63), o (pp. 63-64). Al final de la reseña, el autor hará constar su nombre, su universidad o afiliación sin incluir la dirección postal, y una dirección de correo electrónico.

18. Las reseñas bibliográficas han de enviarse a la Dra. Paloma Pérez-Ilzarbe (pilzarbe@unav.es).

19. Pueden encontrarse unas orientaciones sobre el modo de redactar reseñas en:

http://www.unav.es/publicaciones/anuariofilosofico/contenidos/orientaciones.html

Pamplona, 20 de mayo de 2015 



\section{ÍNDICE ALFABÉTICO DEL VOLUMEN 48 INDEX OF VOLUME 48}

PRESENTACIÓN / PRESENTATION

TOMÁS DE AQUINO Y LAS TRADICIONES ABRAHÁMICAS

Luis Xavier López-Farjeat - Richard C. Taylor

(Editores Asociados)

AUTOCONCIENCIA Y CONOCIMIENTO DE SÍ SEGÚN KANT

Luis Placencia y Alejandro G. Vigo (Editores Asociados)

\section{ESTUDIOS / ARTICLES}

Miquel Beltrán

Vindicación de la subjetividad de los atributos, en Spinoza

The vindication of the subjectivity of attributes in Spinoza

Michael Chase

Quod est primum in compositione, est ultimum in resolutione.

Notes on analysis and synthesis in Late Antiquity

103-139

Quod est primum in compositione, est ultimum in resolutione.

Notas acerca de las nociones de 'análisis' y 'síntesis' en la antigüedad tardía

Rainer Enskat

¿Espontaneidad o circularidad de la autoconciencia?

Kant y el centro cognitivo de la subjetividad que juzga

$443-468$

Spontaneity or circularity of self-consciousness? Kant and

the cognitive centre of a judging subjectivity

Marta García-Alonso

Creencia religiosa y conciencia errónea según Pierre Bayle

$259-280$

Religious belief and erroneous conscience according to Pierre Bayle 
Grzegorz Holub

Karol Wojtyla and René Descartes. A comparison

of the anthropological positions

$341-358$

Karol Wojtyla y René Descartes. Comparación

de sus posturas antropológicas

R. E. Houser

The friar and the vizier on the range of the theoretical sciences

$19-54$

El fraile y el visir sobre el ámbito de las ciencias teoréticas

Max Maureira

Dike, ius o la libertad irrealizada. Sobre la abstracción

del derecho en Hegel

299-314

Dike, ius or the unrealized freedom. On the abstraction

of law by Hegel

Eduardo Molina

Sentimiento de la vida y autoconciencia en Kant

493-514

Feeling of life and self-consciousness in Kant

Matías Oroño

Autoconciencia y corporalidad en la teoría crítica kantiana

$469-491$

Self-awareness and corporeality in Kantian critical theory

Luis Placencia

Autoconocimiento, acción y autointerpretación.

Opacidad y transparencia del saber de sí mismo en

la filosofía práctica de Kant

$543-565$

Self-knowledge, action and self-interpretation. Opacity and

transparency of self-knowledge in Kant's practical philosophy

Rafael Ramón Guerrero

Avempace en las obras de santo Tomás de Aquino

$55-78$

Avempace in the works of Thomas Aquinas

Francisco Romero Carrasquillo

Intellectual elitism and the need for faith in

Maimonides and Aquinas

79-102

Elitismo intelectual y la necesidad de la fe según Maimónides

y Tomás de Aquino

Miguel Saralegui

Un método empírico para una historia compleja. 
La esencia de la historia de la filosofía según Menéndez

Pelayo en La ciencia española

An empirical method for a complex history.

The essence of the history of philosophy according to

Menendez Pelayo in La cienca española

Vicente Serrano

Estética e ironía. La recepción de la filosofía de Fichte por Friedrich Schlegel en el período de Jena

Aesthetics and irony. The reception of Fichte's philosophy

by Friedrich Schlegel in the Jena period

Gabriele Tomasi

Self-knowledge as religious experience. On an aspect

of Kant's conception of the vocation of human beings

$515-541$

Autoconocimiento como experiencia religiosa. Acerca de un aspecto

de la concepción kantiana de la vocación de los seres humanos

BIBLIOGRAFÍA / BIBLIOGRAPHY

\section{RESEÑAS / REVIEWS}

Agazzi, E., Scientific Objectivity and Its Contexts

(Juan José Sanguineti)

$161-164$

Albertson, D., Mathematical Theologies. Nicolas of Cusa

and the Legacy of Thierry of Chartres (Elisabeth Reinhardt)

$567-570$

Aliseda, A., La lógica como herramienta de la razón

(Paloma Pérez-Ilzarbe)

$361-364$

Anders, G., Acerca de la libertad. "Una interpretación del a posteriori" seguido de "Patología de la Libertad. Ensayo sobre la no-identificación" (Carlos Ortiz de Landázuri)

Anrubia, E., La berida y la súplica. Filosofía sobre el consuelo (Encarna Llamas)

Assmann, J., Violencia y monoteísmo

(Mar Rosàs Tosas)

Barrena, S., La belleza en Charles S. Peirce: origen y

alcance de sus ideas estéticas (Raquel Cascales)

$572-574$ 
Beiser, F. C., After Hegel. German Philosophy, 1840-1900 (Carlos Ortiz de Landázuri)

Berti, E., La ricerca della verità in filosofia

(Francisco Sánchez Leyva)

Brösch, M. et al. (eds.), Handbuch Nikolaus von Kues.

Leben und Werk (Víctor Sanz Santacruz)

$371-373$

Broome, J., Rationality through Reasoning (Miranda del Corral)

$171-174$

Burge, T., Cognition Through Understanding. Self-Knowledge, Interlocution, Reasoning, Reflection. Philosophical Essays

(Carlos Ortiz de Landázuri)

De Santis, C., Coscienza e Soggetto. B. Lonergan e l'ermeneutica dell'interiorità (Francisco Sánchez Leyva)

Derrida, J., Heidegger: la question de l'Être et l'Histoire.

Cours de l'ENS-Ulm 1964-1965 (Hernán Javier Candiloro)

Echarte, L. E., Hábitos emocionales en torno a la salud

y la belleza (Javier Bernácer María)

$575-578$

Fani, A., La verità e il bene. 'Veritas', 'bonitas', 'verum' e 'bonum' nelle Questiones disputatae de veritate di Tommaso d'Aquino (Francisco Sánchez Leyva)

Finamore, R. (ed.), Realismo e metodo. La riflessione epistemologica di Bernard Lonergan (Francisco Sánchez Leyva)

$578-581$

Galán, I., El romanticismo y sus mutaciones actuales

(Martha Sánchez Campos)

$185-188$

García-Huidobro, J., ¿Para qué sirve la política?

(María Josefina Saphores L.)

376-379

Geuss, R., A World Without Why

(Carlos Ortiz de Landázuri)

$379-382$

Gomá Lanzón, J., Necesario pero imposible

(Miguel Rumayor)

$383-386$

González, A. M., Sociedad civil y normatividad

(Margarita Mauri)

$188-190$

Hadjadj, F., ¿Cómo hablar de Dios hoy? Anti-manual

de evangelización (Enrique Moros)

190-192

Henry, M., La fenomenología radical, la cuestión de Dios y el problema del mal (Miguel Martí) 
Hüntelmann, R., and Hattler, J. (eds.),

Kervégan, J.-F., ¿Qué hacemos con Carl Schmitt?

(Montserrat Herrero)

194-197

New Scholasticism Meets Analytic Philosophy

(Rubén Pereda)

$386-388$

Laercio, D., Vidas y opiniones de los filósofos ilustres

(Fernando G. Martin de Blassi)

$581-584$

Lazari-Radek, K. de, and Singer, P., The Point of View

of the Universe. Sidgwick and Contemporary Ethics

(Carlos Ortiz de Landázuri)

388-391

López Quintás, A., La ética o es transfiguración o no es nada

(Álvaro Abellán-García Barrio)

$584-587$

Martínez Carrasco, A., D'Ors y Ortega frente a frente

(Alfons Puigarnau)

587-591

Moya Cañas, P., El conocimiento: nuestro acceso al mundo.

Cinco estudios sobre filosofía del conocimiento

(María del Rosario Newman L.)

$197-200$

Müller, T., Der junge Cusanus. Ein Aufbruch in das 15.

Fabrhundert (Víctor Sanz Santacruz)

391-393

Natali, C., Aristotele

(David Torrijos Castrillejo)

393-396

Neuman, M. R., Metafísica de la inteligibilidad y

la autoconciencia en Tomás de Aquino (Patricia Moya C.)

592-595

Nubiola, J. y Barrena, S., Charles S. Peirce (1839-1914):

Un pensador para el siglo XXI

(Pedro Russi)

396-398

Obrist, H. U., Ai Weizvei Conversaciones (Diana A. Jordá F.) 595-598

Oderberg, D. S. (ed.), Classifying Reality

(Carlos Ortiz de Landázuri)

200-203

Pareyson, L., Verdad e interpretación (Pablo Blanco)

598-601

Pasnau, R. \& Dyke, C. van (eds.), The Cambridge History

of Medieval Philosophy (Carlos Ortiz de Landázuri)

$602-605$

Russell, L., Evil. A Philosophical Investigation

(Carlos Ortiz de Landázuri)

605-607 
Sandel, A. A., The Place of Predujice. A Case for Reasoning within the World

(Carlos Ortiz de Landázuri)

$399-401$

Schwember Augier, F., Libertad, derecho y propiedad. El fundamento de la propiedad en la filosofía del derecho de Kant y Fichte (Emiliano Acosta)

$402-405$

Sellés, J. F., Los tres agentes del cambio en la sociedad civil.

Familia, universidad y empresa (Melissa Llauce Ontaneda) 203-206

Shrimpton, P., The 'Making of Men'. The Idea and reality of Newman's university in Oxford and Dublin (Jaime Nubiola)

$608-611$

Sison, A. J. G., Happiness and Virtue Ethics in Business.

The Ultimate Value Proposition (Germán Scalzo)

$611-614$

Torrijos-Castrillejo, D., Anaxágoras y su recepción

en Aristóteles (Diana María Murguía Monsalvo)

$614-617$

Zalamea, F., Prometeo liberado. La emergencia creativa en los maestros del siglo XIX y XX (Mateo Rodríguez-Arias)

$618-620$ 


\section{CUADERNOS DE ANUARIO FILOSÓFICO}

\section{SERIE UNIVERSITARIA}

Petición de Cuadernos: cuadernos@unav.es

No 237 Jorge Mario Posada, Sobre el logos como unificación matemática de la dual intelección racional en la persona bumana (2011)

No 238 Mariona Villaro, Naturaleza bumana y libertad (2011)

No 239 Juan Fernando Sellés, Dietrich de Freiberg (Teodorico el Teutónico, 12501310/20). Claves filosóficas de un maestro olvidado (2011)

No 240 Susana Christiansen, La unidad dinámica de la acción bumana, desde la teleología de Tomás de Aquino (2011)

No 241 Ángel Luis González (ed.), La intermediación de filosofía y teología (2011)

No 242 José Díez Deustua, El concepto de deliberación en el comentario de Santo Tomás de Aquino al libro VI de la Ética a Nicómaco (2012)

$\mathrm{N}^{\circ} 243$ Mario Molina Maydl, El surgimiento de la sensibilidad pura (2012)

No 244 Ángel Luis González (ed.), Metafísica modal en G. W. Leibniz (2012)

No 245 Juan Fernando Sellés, Claves metódicas de acceso a la obra de Soren Kierkegaard (2012)

No 246 Agustín Echavarría / Juan F. Franck (eds.), La causalidad en la filosofía moderna. De Suárez al Kant precrítico (2012)

No 247 David González Ginocchio / M ${ }^{\mathrm{a}}$ Idoya Zorroza (eds.), Estudios sobre la libertad en la filosofía de Leonardo Polo (2013)

No 248 Enrique V. Muñoz Pérez, Heidegger y Scheler: Estudios sobre una relación olvidada (2013)

No 249 Rafael Tomás Caldera, Misterio de lo real. Vocación al amor (2013)

No 250 Sebastián Buzeta, Sobre el conocimiento por connaturalidad (2013)

No 251 Agustín Navarro, Arte y conocimiento. La estética de W. Dilthey (2013)

\section{SERIE DE ESTÉTICA}

Petición de Cuadernos: cfhuarte@unav.es

No 5 Margarita Puigserver, La obra de Chopin en Mallorca en el invierno de 1838-39 (2003)

No 6 Carlos Ortiz de Landázuri, Gombrich: una vida entre Popper y Wittgenstein (I) (2003)

No 7 Carlos Ortiz de Landázuri, Gombrich: una vida entre Popper y Wittgenstein (II) (2003)

No 8 Paula Lizarraga y Oihana Robador, Conversación con Venancio Blanco (2007) 


\section{SERIE DE PENSAMIENTO ESPAÑOL}

Petición de Cuadernos: izorroza@unav.es

$\mathrm{N}^{\mathrm{o}} 42 \quad \mathrm{M}^{\mathrm{a}}$ Idoya Zorroza (ed.), Causalidad y libertad. Y otras cuestiones filosóficas del Siglo de Oro español (2011)

No 43 Sergio Raúl Castaño, La interpretación del poder en Vitoria y Suárez (2011)

$\mathrm{N}^{\circ} 44$ Juan Cruz Cruz, La interpretación de la ley según fuan de Salas (2011)

$\mathrm{N}^{\circ} 45$ Juan A. García González (ed.), El conocimiento de lo físico, según Leonardo Polo (2011)

No 46 Miguel Rumayor, El yo en Xavier Zubiri (2013)

$\mathrm{N}^{\circ} 47$ Ángel Luis González - David G. Ginocchio, Pensamiento, lenguaje y realidad. Estudios sobre la filosofía de Leonardo Polo (2012)

$\mathrm{N}^{\circ} 48$ Juan Fernando Sellés, Sustancia, autoconciencia y libertad. Estudio sobre la antropología de Antonio Millán-Puelles (2013)

$\mathrm{N}^{\circ} 49$ Mauricio Beuchot, Ensayos sobre escolástica bispana (2013)

No 50 Rafael Corazón González, La idea de ente. El objeto de la metafísica en la filosofía de Leonardo Polo (2014)

No 51 Francesco de Nigris, Sustancia y persona. Para una bermenéutica de la Metafísica de Aristóteles según la razón vital (2013)

$\mathrm{N}^{\mathrm{o}} 52$ Jean Paul Coujou / $\mathrm{M}^{\mathrm{a}}$ Idoya Zorroza, Bibliografía vitoriana (2014)

No 53 Juan Fernando Sellés, Del dualismo alma-cuerpo al monismo corporalista. La antropología de Pedro Laín Entralgo (2014)

No 54 Juan A. García González (ed.), Escritos en memoria de Leonardo Polo. I: Ser y conocer (2014)

No 55 Juan A. García González (ed.), Escritos en memoria de Leonardo Polo. II: Persona y acción (2014)

\section{SERIE CLÁSICOS DE SOCIOLOGÍA}

Petición de Cuadernos: angarcia@unav.es

No 16 Fernando Múgica Martinena, E. Durkbeim: La constitución moral de la sociedad (III). Los elementos de la moralidad y la configuración social de la vida ética (2005)

No 17 Fernando Múgica Martinena, E. Durkheim: En el umbral de lo sagrado. La formación de la sociología de la religión (2006)

No 18 Fernando Múgica Martinena, E. Durkheim: El principio sagrado (I). La representación de lo sagrado (2006)

No 19 Fernando Múgica Martinena, E. Durkbeim: El principio sagrado (II). De la experiencia ritual de lo sagrado a la verdad sociológica de la religión (2006)

No 20 Fernando Múgica Martinena, E. Durkbeim: Arqueología de lo sagrado y futuro de la religión. Historia de una polémica (2007) 


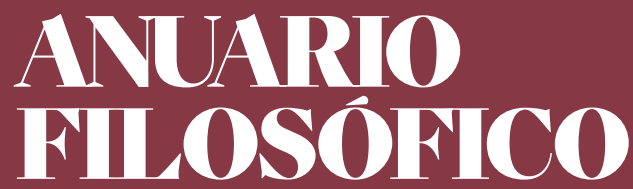

REVISTA CUATRIMESTRAL FUNDADA EN 1968

SERVICIO DE PUBLICACIONES DE LA UNIVERSIDAD DE NAVARRA

PAMPLONA / ESPAÑA

ISSN: 0066-5215 